\title{
Psychological Notes on the Motives for Thrift
}

\author{
By Edward L. Thorndike \\ Teachers College, Columbia University
}

\begin{abstract}
$A$ COMPLETE inventory of the A motives for thrift and appraisal of each from the point of view of the common good would require thought and investigation by many men for many years. It would presuppose adequate study of the actual working of scores of agencies such as savings banks, building loan societies, installment-plan selling, deferred salary bonuses, and the like; and indeed of all forms of delayed versus immediate use of purchasing power.
\end{abstract}

In default of such adequate information, principles should at least be based on what knowledge is available of the ways in which, and the reasons for which, children and adults do savethat is, delay the use of such purchasing power as they from time to time obtain. The writer, however, lacks even this knowledge and can offer only certain facts and principles based on the general psychology of motives. These may perhaps be helpful.

\section{Psychological Basis of Saving}

The original nature of man,- the equipment of capacities and tendencies, desires and aversions which he inherits as he inherits a back-bone, upright posture, and power to laugh and cry-predisposes him rather against saving. Except for the tendencies to bring an attractive object to one's lair and cherish it there and to collect and hoard certain small objects, man is by nature improvident. The parental instincts lead him to feed, nurse, cuddle and protect the infant and child, but not to save for its future welfare. The tendencies to acquiring and hoarding may be used as a starting-point for habits of saving which may later be refined into habits of real thrift: they are, however, by nature productive only of indiscriminate saving of material objects; and it is doubtful whether they do much more good by the energy they supply, than they do harm by its undesirable manifestations.

On the other hand there are, working against thrift, the very strong original tendencies toward gratifying the gross sensory appetites, and toward display, mastery and approval. Everybody understands the potency of the sensory appetites, and their essential conflict with thrift. The cruder inborn passions of approval, getting and mastery and their effect on thrift are not so well understood.

\section{Natural Tendencies of Man}

The essential facts are as follows: To the situation, "intimate approval, as by smiles, pats, admission to companionship and the like, from one to whom he has the inner response of submissiveness," and to the situation, "humble approval, as by admiring glances, from anybody," man responds originally by great satisfaction. The withdrawing of approving intercourse by masters and looks of scorn and derision from anyone originally provoke a discomfort that may strengthen to utter wretchedness. The reader will understand that the approval and disapproval which are thus satisfying and annoying to the natural man are far 
from identical, in either case, with the behavior which proceeds from cultivated moral approbation and condemnation. The sickly frown of a Sundayschool teacher at her pupil's mischief may be prepotently an attention to him rather than the others, may contain a semi-envious recognition of him as a force to be reckoned with, and may even reveal a lurking admiration for his deviltry. It then will be instinctively accepted as approval.

Darwin long ago noted the extraordinarily ill-proportioned misery that comes from committing some blunder in society whereat people involuntarily "look down" on one for an instant. Except for him, little attention has been paid to the originality of the hunger of man for the externals of admiration and the intolerability of objective scorn and derision. Yet these forces of approval and disapproval in appropriate form, from those above and those below us in mastery. status, are and have been potent social controls. For example the discipline of a humane home or school today relies almost entirely upon such approval from above, and finds it even more effective than severe sensuous pains and deprivations. The elaborate paraphernalia and rites of fashion in clothes exist chiefly by virtue of their value as means of securing diffuse notice and approval. The primitive sex display is now a minor cause: women obviously dress for other women's eyes. Much the same is true of subservience to fashions in furniture, food, manners, morals, and religion. The institution of tipping, which began perhaps in kindliness and was fostered by economic self-interest, is now well-nigh impregnable because no man is brave enough to withstand the scorn of a line of lackeys whom he heartily despises, or of a few onlookers whom he will never see again.

Best of all illustrations of the potent craving for objective approval, perhaps, is offered by Veblen's brilliant analysis of the economic activities of the leisure class. These he finds to be essentially vicarious consumption and conspicuous waste, or the maintenance of a useless retinue and public prodigality in order to show that you have more than you can use, and so to fix upon you the admiring glances of those who can afford to waste less or nothing at all.

To manifest approving and disapproving behavior is as original a tendency as to be satisfied and annoyed by them. Smiles, respectful stares and encouraging shouts occur, I think, as instinctive responses to relief from hunger, rescue from fear, gorgeous display, instinctive acts of strength and daring, victory, and other impressive instinctive behavior that is harmless to the onlooker. Similarly, frowns, hoots and sneers seem bound as original responses to the observation of emptyhandedness, deformity, physical meanness, pusillanimity, and defect.

As things are and have been in most communities, thrift reduces, or at least delays, the chance to win approval by "relief from hunger, gorgeous display and other impressive behavior," and to attain a superior mastery-status. The "tight-wad" is scorned; the meanly dressed girl feels inferior. In popular juvenile and adult fiction, which mirror rather faithfully the instinctive proclivities of man, the necessity for thrift is at the best a burden which it is heroic to endure. The exercise of prudence about money and property is tolerated if not actually scorned.

In a less degree the instincts of adventure, rivalry, sex pursuit, parental love and general kindliness are also 
against thrift. Parents, for example, tend by original nature to indulge their children in food and toys, but not to take out life insurance. To make man thrifty his original love of notice, approval, mastery and sport, as well as his cruder animal appetites, have to be counteracted by other tendencies or amended by dexterous training.

\section{Inhibition by Rational Insight}

These may be counteracted in many ways, two of which are of special interest,-inhibition by rational insight and inhibition by unreasoned repression. Inhibition by rational insight is one aim of training in good homes, schools, shops and factories. Children and others are taught by precept and by example that twenty dollars is better if saved for a bicycle than if frittered away in buying candy and trifling entertainments. They are taught that it is well to provide for future as well as for present needs, and for unforeseen needs as well as for those at present envisaged. They are taught to care for property which they or others may need later, even though there may be a present enjoyment in destroying or neglecting it. In general, they are taught the meaning of money and property as means of deferred as well as present enjoyment and purchasing power, and to consider their deferred use. More or less elaborate attempts may be made to teach them to esteem prudent behavior as well as, or in place of, size, beauty, courage, gorgeous display and lavishness. All this is a part of the general program of teaching wisdom and morality, and is useful if enough pedagogical skill is used. The person learns to value thrift rightly and redirects his instinctive appetites by such learning.

\section{Inhibition by Unreasoned Repression}

When sufficient pedagogical skill is not used to give an appreciation of the reasons, or when the reasons given for being thrifty are not really rational, we have inhibition by unreasoned repression. In this case the reason ostensibly associated with the acts of saving is incomprehensible or valueless to the saver, the active reason or motive for him being something quite different. Thus a little child may be taught to put his money in a bank "because all good children do so" or "so that you will have money for an education" or "because it is wrong to spend all your money for candy and toys." The active force in his saving is not acceptance of these maxims, but fear of parental rebuke, or love of praise, or the pride at displaying his savings, or a more comfortable feeling when other children are displaying theirs.

In such cases the child often, perhaps usually, forgets what the active force was and has left chiefly or solely a diffuse feeling that he ought to save, because it is the thing one ought to do, what the philosophers might call a categorical imperative. Such a motive is strong so long as the individual cherishes it. He can withstand arguments and persuasive attacks. Holding his position for no reasons that he knows of, he cannot be dislodged from it by reasons. The motive is weak in the sense that if it is once lost, it can be recovered only by slow re-creation.

Redirecting the Tendencies of Approval and Scorn

Instead of thus counteracting prodigal tendencies from without by reasoned or unreasoned habits, we may try to amend them, attacking them as it were from within. 
The desire for approval can theoretically be made to favor thrift as much as it now favors lavishness. And practically such redirection of popular applause can be carried much further than past history might lead us to expect. Modern advertising, if given free scope, can almost guarantee that in a given year any defined population will approve a color combination which a year ago it detested.

It would probably not be hard to get the world to pity or scorn a man who had to have a chauffeur drive him as it now pities or scorns a man who has to be carried in another's arms. People could be taught to regard the child who went to a private school, with large tuition fees, as an unfortunate who was not expected to get on in the world without special favors,as a "lame duck" who required a large handicap, as the weak mind who had to have a pedagogical doctor and special medicine. The woman who lived in a palatial house with a retinue of maids and lackeys might come to be viewed as insane - like a woman who should wear twenty gowns one over the other or ten hats one on top of the other, to show that she could afford that many, or who rose each half hour of the night to change to a different bedroom.

If girls and women all wore a standard dress and if it became the custom to regard any excess of quality or adornment as the effort of an inferior physique to hide its unattractiveness, the misery of unsatisfied longings for personal adornment in the poor, and the still more debasing glorification of one's self for merits really belonging to one's dressmakers and milliners, might be notably decreased. In certain girls' schools something much like this is actually attained.
Whether we try to inhibit prodigal tendencies by rational insight or to amend them by attaching the zest of adventure, power, notice and approval to thrifty behavior, success requires not only that we use right principles of persuasion and habit formation, but also that we be ingenious in the details of human engineering. The former are now fairly well known; the full development of the latter will require the time and thought of many gifted men, and much experimentation and verification. The concrete suggestions which make up the rest of this chapter are at best only a millionth part of what adequate talent and work may achieve.

\section{Improving Thrift by Rational INSIGHT}

The worst form of thriftlessness is expenditure for objects or conditions which give no essential satisfaction to the buyer or anybody else. Such utter waste is of greater magnitude than might be supposed. We buy many things which we soon find out we do not want at all. We buy vastly more things which we think we want, but only because we have been taught to believe that we want them. Let some one teach us to believe that we do not want them and our net satisfactions are increased with a decrease in costs. The coat $I$ am wearing has buttonholes and buttons on the sleeves whose only value hangs by a convention which is itself essentially valueless to all. We pay for many objects and conditions when a different and cheaper object or condition would have suited us far better. Thus to the average girl of eighteen, an automobile and the privilege of driving it is far more satisfying than the same automobile and a chauffeur to drive her in it. To the 
girl's mother the pride that her daughter can take care of herself may be far more satisfying, as well as cheaper, than the knowledge that there is a servant to take care of her. The foolish father pays ten dollars for carved animals for his child who would infinitely prefer a fifty-cent knife and a stick of wood to cut. Leaders of the public should teach it to know what it really wants and to save the expense of paying for what makes it miserable.

It has been an unfortunate custom for poets, philosophers, literary men and men of science to regard money as in some sense ignoble. We have been taught that the cultivated man cares little for money, or that money will not buy the best things in the world, or that we do not wish our children to care especially about making money. This is, however, false or at least fallacious, what is really meant being properly that the average uses of money are less noble than the average uses of wisdom, honesty, courage, female virtue, health and the like. Money is purchasing power, and wisdom, honesty, courage, female virtue and health are purchasable. Purchasing power rightly used could, for example, reduce prostitution by a large percent, and eliminate tuberculosis entirely.

The wise and cultivated man may give the world a new scientific truth directly, if he has the talent to discover it. Any man can ensure giving a new scientific truth to the world if he will purchase a perennial research fellowship of $\$ 10,000$ instead of building himself a house for a quarter of a million dollars. A woman may add one to the roster of female virtue by preserving her own, but she can ensure the addition of many by spending money judiciously to provide for healthy recreation of girls or for the segregation of the feeble-minded.

\section{The Nature of Saving}

The fact that saving is simply deferred spending is perhaps worth making clearer to children and adults of uncritical minds. Saving is often felt as an essential deprivation, for example by children whose savings go year after year into a bank and never come out. If he is to be rational, the saver should think of his bank account as a fund of purchasing power; and should from time to time spend money that he has saved. Saving thus becomes dissociated from mere self-denial and a restricted life and associated with the sense of mastery and self-confidence which ordinary human nature so highly values. It is too much to expect children or unintelligent adults to save rationally for the needs of old age or sickness or for a reserve for unforeseen emergencies. Prudence with them may consist in going without candy to have a bicycle, or in denial in food, dress and amusements to have a home of their own. The foresight thus encouraged may extend to an appreciation of the value of a reserve of general purchasing power.

It may be desirable to give more people and at a younger age the conception of true economic waste. Many children and adults would be willing to save for the public if they were brought to consider the matter. They destroy in neglect what they cannot themselves use for their own satisfaction, not because they wish to injure others to save themselves a very slight inconvenience, but because they do not consider the interest of the others at all. Their deficiency is intellectual rather than moral, and is curable by reasoning and persuasion. 
Also many children and adults confuse the virtue of generosity and the virtue of true economic thrift and secure the former at the expense of the latter. In the common case of discarded clothes, for example, the average American would regard himself as generous and thrifty when he gave away a suit of clothes. He is generous to the extent of the money value of the old clothes minus the money value of his own trouble in selling them to an old-clothes dealer. But he cannot credit himself with any true economic thrift, except in so far as he chooses as the beneficiary someone who will surely make effective use of the clothes. True economic thrift is in general much more surely secured if he sells the clothes; the proceeds he may use as generously as he chooses.

\section{The Stimulus to Saving}

The interest in savings is accentuated by a concrete and obvious thing to embody, represent, or at least measure it. A bank with the pile of pennies therein increasing; a farm growing by the purchase of field after field-these are more stimulating to the average mind of young or old than a bank book with ink entries or a safety-deposit box of securities. The saver's record of his savings may well be made more corporeal and obvious than it would be made if the clerical convenience and accuracy of the record were the only desideratum. In the case of little children, for example, the savings account proper might be duplicated by affixing a red seal for each quarter, a silver seal for each dollar, and a gold seal for each five dollars. Passing the ten dollar mark might be celebrated by promotion to a larger-sized book. These devices may be criticized as childish, but with little children childish motives may well be employed.

Where Redirecting the TendenCies to Approval aNd Scorn Should Begin

It appears probable that men and women of notable achievement or popularity or both can encourage thrift greatly by denying to themselves and their families all forms of ostentatious expenditure. If the ablest lawyers, surgeons, bankers, manufacturers, ballplayers, athletes, salesmen, musicians and actresses show a contempt for wasteful display in their lodging, service, food and dress, the fashion will in large measure spread to those who observe them directly and to the multitudes who observe them through the media of newspapers and magazines. If the most popular politicians, singers, authors, and leaders of society (whatever that may be) let their merit attach itself to plain living, luxurious display will soon lose a large measure of its reinforcement. It might become not only vulgar but also eccentric, the behavior of a crank.

Certain forms of ostentation that were considered entirely suitable five hundred years ago would be considered vulgar now, because men and women of eminence have abandoned them. Possibly the same process of association could attach vulgarity to all forms of conspicuous waste. As fast as Veblen's conspicuous waste is made synonymous with conspicuous vulgarity, imbecility and inferiority, it will tend to be replaced by conspicuous thrift, or (if we are ingenious enough in our social engineering) by modest thrift.

Thrift should then be begun with the rich, important, able, and popular. So long as it is advocated as the virtue 
of the poor and lowly, the young and struggling, the propaganda will be largely self destructive. Jeffersonian simplicity can be inculcated in a land where universal ambition is encouraged only when men of Jefferson's status live simply. It is not only bad taste and bad morals for the ostentatious rich to preach thrift to the poor; it is also largely time wasted. The man who by thrift in youth is able to indulge in luxurious display later is more of an encouragement to luxurious display than to thrift. His example when he was an unknown struggler is of little force; what he does when he is known as successful has publicity and power.

If the world as a whole is to be efficient, its mighty ones must distinguish sharply between expense for efficiency and expense for display, and leave the latter to peacocks, monkeys, the feebleminded, and women who have to make themselves saleable. They must also, and this will be much harder, teach their wives and daughters to do likewise. 